\title{
ZDRAVSTVENI KOTIČKI IN IZOBRAŽEVANJE ZA ZDRAVJE V SPLOŠNIH KNJIŽNICAH
}

\section{POVZETEK}

$V$ članku je prikazana raziskava o zdravstvenih kotičkih $v$ slovenskih splošnih knjižnicah. Namen je bil analizirati dejavnosti zdravstvenih kotičkov in predstaviti prednosti ter pomanjkljivosti oz. izzive. Uporabljene so bile različne metode zbiranja podatkov: intervjuji s knjižničarji, analiza spletnih strani in družbenih omrežij ter opazovanje. Rezultati so pokazali, da se knjižnice zavedajo pomena izobraževanja za zdravje in organizirajo veliko število izobraževanj za zdravje, vendar pa se ta le v manjši meri izvedejo $v$ zdravstvenih kotičkih. Zdravstveni kotički so urejeni in smiselno umeščeni v knjižnični prostor, potrebovali pa bi nove strategije za izobraževanje za zdravje. Poseben izziv pri načrtovanju in izvajanju izobraževanja za zdravje so informacijsko slabše pismeni uporabniki, saj mnogo priložnosti pridobivanja informacij ponujajo prav splet in družbena omrežja. S spremenjeno strategijo izobraževanja bodo lahko v prihodnosti zdravstveni kotički imeli močnejšo vlogo pri ozaveščanju uporabnikov na področju zdravja.

Ključne besede: splošne knjižnice, zdravstveni kotički, zdravje, izobraževanje

\section{HEALTH ZONES AND HEALTH EDUCATION IN PUBLIC LIBRARIES - ABSTRACT}

The article presents research on health zones in Slovenian public libraries. The aim of the research was to analyse their activity and to identify their advantages and disadvantages or challenges. The data collection methods used were interviews with librarians, analysis of websites and social networks, and observation. The results of the research show that libraries are aware of the importance of health education and organise a large number of health education events. However, these are offered only to a limited extent in the health zones themselves. While health zones are well organised and suitably embedded in library spaces, new strategies for health education are needed. One challenge in planning and delivering health education, particularly when it comes to less information literate users, are the many opportunities to acquire information online and on social networking sites. With the change in education strategy, health zones can play a bigger role in raising awareness among health users in the future.

Keywords: public libraries, health zones, health, education

Doc. dr. Katarina Švab, Oddelek za bibliotekarstvo, informacijsko znanost in knjigarstvo, Filozofska fakulteta Univerze v Ljubljani, katarina.svab@ff.uni-lj.si 


\section{UVOD}

Splošna knjižnica je javna služba, ki ima izobraževalno, informacijsko, kulturno in razvedrilno vlogo v lokalni skupnosti in družbi nasploh. V današnji družbi so knjižnice vedno bolj pomembne tudi na področju ozaveščanja in izobraževanja o zdravju, zdravem načinu življenja, dobrem počutju itd. Knjižnice podpirajo prebivalce in organizacije v lokalni skupnosti pri pridobivanju, vrednotenju in uporabi zdravstvenih informacij.

Mreža 58 slovenskih splošnih knjižnic je zelo dobro organizirana, saj na 273 lokacijah vsem prebivalcem omogoča uporabo knjižničnih storitev (Narodna in univerzitetna knjižnica, 2021). Storitve in dejavnosti na področju izobraževanja za zdravje so stalna ponudba vseh slovenskih splošnih knjižnic z namenom uresničevanja pravic državljanov do dostopa do informacij s področja zdravstva in pravice do obveščenosti in samostojnega odločanja o zdravju (Nacionalni svet za knjižnično dejavnost, 2018; Zakon o pacientovih pravicah, 2008, čl. 5). Četudi je informacijska in izobraževalna vloga splošnih knjižnic namenjena vsem prebivalcem, pa knjižnice niso vključene v projekt Dvig zdravstvene pismenosti v Sloveniji (Nacionalni inštitut za javno zdravje [NIJZ], 2021).

Namen prispevka je na podlagi rezultatov analize virov in intervjujev podati odgovore na izzive knjižnic in lokalnih skupnosti pri zagotavljanju kakovostnih informacij s področja varovanja zdravja in izobraževanja za zdravje. Kot posebno prakso za ozaveščanje in izobraževanje o zdravju smo izbrali zdravstvene kotičke, ki bodo predstavljeni v drugem delu članka.

\section{ISKANJE ZDRAVSTVENIH INFORMACIJ}

V okviru raznolikih vrst pismenosti se je razvila tudi zdravstvena pismenost, ki je pomemben koncept za izobraževanje o zdravju v knjižnicah. Eden izmed vidikov zdravstvene pismenosti je izbor zdravstvenih informacij iz najbolj relevantnih virov. Raziskave kažejo, da posamezniki, ki imajo nizko razvito zdravstveno pismenost, opravijo manj pregledov, se pozneje odločijo za obisk zdravnika, imajo težave z razumevanjem informacij pri zdravniku in slabše skrbijo za svoje zdravje (Coulter idr., 2006; Estacio in Comings, 2013; Kickbusch, 2008; Rubenstein, 2016; Sørensen idr., 2012). Ljudje, ki iščejo zdravstvene informacije, se med seboj razlikujejo glede na spol, starost, izobrazbo, zdravstveno stanje, socialno-ekonomski status ter glede načinov in razlogov pridobivanja informacij. Po nekaterih raziskavah najpogosteje iščejo zdravstvene informacije ženske z višjo izobrazbo in višjim dohodkom ter starejše osebe (Anker idr., 2011; Komel, 2016; Zickuhr, 2010). Šinko (2012) je ugotovila, da starejši kot so uporabniki, več zanimanja kažejo za izobraževanje na področju zdravja (o boleznih, alternativnih metodah zdravljenja itd.). Ob tem velja poudariti, da je bila izobrazbena sestava vzorca višja od povprečne izobrazbe v Sloveniji.

Najpogosteje se zdravstvene informacije iščejo na spletu, ki je najbolj priljubljen zaradi enostavnosti iskanja, hitrosti in spoznavanja izkušenj drugih (Pletneva idr., 2011; Ramšak, 2011). Velik delež uporabnikov uporablja splet za iskanje informacij o boleznih, prehrani, gibanju in dietah (Andreassen idr., 2007; Fox in Duggan, 2013). Večina začne iskanje s 
splošnim iskanjem v iskalnikih in ne na zdravstvenih spletnih straneh ter v povprečju med rezultati iskanja pregleda dve do pet spletnih strani (Fox in Rainie, 2002). Uporabniki menijo, da je iskanje po spletu težko, kot zahtevno pa ocenjujejo tudi presojanje verodostojnosti pridobljenih informacij (Huotari idr., 2015). Dandanes je mnogo zdravstvenih informacij tudi na družbenih omrežjih, a večina starejših uporabnikov (nad 60 let) nikoli ni bila prijavljena na Facebookove strani o zdravju in zdravem načinu življenja (Pálsdóttir, 2014). Razlogi za iskanje zdravstvenih informacij se razlikujejo glede na zdravstveno stanje osebe pred zdravstveno obravnavo, med njo in po njej (Delić idr., 2006; Kozel, 2010).

\section{PREGLED VRST IZOBRAŽEVANJA ZA ZDRAVJE V KNJIŽNICAH}

Izobraževanje za zdravje se v splošnih knjižnicah že dolgo izvaja. Najstarejša elementa pri razvoju ozaveščanja in izobraževanja za zdravje sta knjižnična zbirka in referenčni pogovor. Knjižnice posebno skrb posvečajo izgradnji in razvoju knjižnične zbirke s področja zdravja in zagotavljajo svojim uporabnikom individualne informacije. Poleg tega organizirajo neformalna izobraževanja za uporabnike, ozaveščajo lokalno skupnost o skrbi za zdravje in sodelujejo z zdravstvenimi institucijami. Kot četrti element omenimo tudi profesionalno izpopolnjevanje knjižničarjev na področju iskanja in vrednotenja zdravstvenih informacij (Bennett-Kapusniak, 2018; Rubenstein, 2016). Vse štiri ravni se v praksah knjižnic medsebojno prepletajo.

Knjižnice so javni prostor, tudi za osebe, ki se soočajo s telesnimi in duševnimi boleznimi, ter zatočišče mnogim marginaliziranim skupinam (Morgan idr., 2016), zato so različne dejavnosti izobraževanja za zdravje namenjene različnim skupinam. Omogočanje dostopa vsem do informacij in gradiva na različnih nosilcih in v različnih formatih je ena glavnih nalog knjižnic, ki je tudi zakonsko določena v Zakonu o knjižničarstvu (2001).

Viri za razvoj znanja o zdravju so razvrščeni v knjižnične zbirke in organizirani po univerzalni decimalni klasifikaciji (UDK), razen v Mestni knjižnici Kranj. Večina tovrstnega tiskanega gradiva je razporejena v skupini 61 (UDK 61 - medicina) in podskupinah. Ker izobraževanje za zdravje vključuje telesno in duševno zdravje, naj omenimo, da so dela o duševnem zdravju razvrščena v skupino 159.9 , nekatera gradiva pa so tudi pri družbenih vedah (UDK 331, 355, 364).

Uporabniki knjižnice bolj zaupajo tiskanim kot spletnim virom in zelo malo uporabljajo vire, ki so navedeni na spletni strani knjižnice (Ingham, 2014). Pri iskanju virov pogosto prosijo za pomoč knjižničarja. Če uporabnik za pomoč o zdravstvenih informacijah prosi knjižničarja, traja referenčni pogovor od 10 do 30 minut (Linnan idr., 2004). Knjižničarji, ki v referenčnem pogovoru razrešujejo informacijske potrebe uporabnika, ne dajejo razlag o zdravju, temveč predvsem o pridobivanju relevantnih, zanesljivih informacij. Ker so uporabniki knjižničnih virov različni, lahko nastane težava, če imajo knjižnice relevantne vire, a so informacije $\mathrm{v}$ teh virih preveč zahtevne ali vsebujejo strokovno terminologijo in so zato splošnemu uporabniku nerazumljive (Powell idr., 2011). Večina knjižničarjev zdravstvenih informacij ne obravnava kakorkoli drugače kot informacije z 
drugih področij, a se zavedajo, da morajo uporabniku postavljati podvprašanja previdno, saj nekateri težko spregovorijo o svoji bolezni (Resman, 2018; Rubenstein, 2016). Zato v Zdravstvenih in medicinskih smernicah Sveta referenčnih in uporabniških storitev Ameriškega knjižničarskega združenja (2015) navajajo načine za posredovanje informacij s strani knjižničnega osebja, ki pri tem potrebuje posebne kompetence in občutek za sočloveka. Mnoge knjižnice so pozorne na osebe, ki v knjižnico ne morejo priti, in jim omogočajo referenčni pogovor prek različnih komunikacijskih kanalov ter jim zagotavljajo dostavo gradiva na dom (po pošti, dostava s kolesom ...). Kot obliko svetovanja lahko štejemo tudi telefonski pogovor.

Uporabniki se lahko srečujejo še z drugimi ovirami, kot je pomanjkanje bralne ali informacijske pismenosti (Resman, 2018). Do teh uporabnikov lahko knjižničarji pristopijo posredno, npr. z organizacijo različnih prireditev, ki imajo namen razvijati ozaveščenost o zdravju in so sicer namenjene vsem uporabnikom. Dogodki so oblikovani kot predstavitve knjig (npr. v okviru literarnih prireditev) in kot predavanja (v okviru ciklov ali kot priložnostna predavanja na specifično tematiko). Predavanja in delavnice vodijo zdravstveni delavci, prostovoljci, večinoma upokojeni strokovnjaki ali študenti zdravstvenih strok.

Dandanes knjižnice razvijajo izobraževalne strategije ozaveščanja tudi s sodobnimi komunikacijskimi mediji: vse slovenske splošne knjižnice imajo stran na Facebooku, manj pa so dejavne na Instagramu in Twitterju (Švab, 2020). Od začetka pandemije covida-19 se je na družbenih omrežjih pojavilo veliko informacij, a hkrati tudi dezinformacij o zdravju, t. i. fake news. Vendar pa so le nekatere knjižnice obveščale in ozaveščale o trenutni zdravstveni situaciji oz. zdravju nasploh.

$\mathrm{V}$ tujini imajo pri zagotavljanju in posredovanju zdravstvenih informacij in izobraževanju za zdravje najpomembnejšo vlogo medicinske knjižnice. ${ }^{1}$ Njihov namen je razširiti vlogo knjižnic pri posredovanju zdravstvenih informacij na laično javnost. Splošne knjižnice se povezujejo z medicinskimi knjižnicami in drugimi zdravstvenimi organizacijami, predvsem v lokalnem okolju (Collins, 2015). Sodelovanje splošnih knjižnic v aktivnostih izobraževanja za zdravje v razvitih državah podpirajo tudi ministrstva za zdravje, saj želijo spodbuditi uporabnike $\mathrm{k}$ uporabi zanesljivih virov informacij. $\mathrm{V}$ ta namen izvajajo predstavitve virov zdravstvenih informacij $\mathrm{v}$ knjižnici in na drugih dogodkih $\mathrm{v}$ lokalni skupnosti, pripravljajo razstave na temo zdravja, zdravstvenopromocijske aktivnosti v lokalni knjižnici (npr. meritve krvnega tlaka), delavnice s specifično zdravstveno tematiko itd., ponekod pa so vzpostavili zdravstvene kotičke (ang. Health zones), kjer so na razpolago razne brošure, tudi društev, revije, prospekti, plakati, zloženke s seznami priporočene literature s področja zdravja (Kodela, 2015; Radick, 2015).

1 Ameriška Nacionalna knjižnica za medicino z bazo MedlinePlus (https://medlineplus.gov/), Združenje medicinskih knjižnic s sekcijo Customer and Patient Health Information Caucus (CAPHIC; https://www. mlanet.org/caphis) in evropsko združenje EAHIL s sekcijo Public Health Information Group (PHIG; http:// eahil.eu/sig-2/public-health-information-group/). 
Slovenske splošne knjižnice so razvile kar nekaj projektov izobraževanja za zdravje. Prvi projekt »Javne knjižnice za zdravje občanov« se je začel leta 2007 pod okriljem Rdečega križa v Celju. Leta 2011 je bil izpeljan projekt »Zdravstveni kotiček «, v katerem so sodelovale Centralna medicinska knjižnica, Mestna knjižnica Ljubljana, enota Knjižnica Otona Župančiča, Knjižnica Mirana Jarca Novo mesto in Mariborska knjižnica. Knjižničarji so se udeležili izobraževanja Centralne medicinske knjižnice, ki je tudi oblikovala zbirko spletnih virov (Rožić idr., 2010).

Knjižnice imajo zelo dobro in široko razvejeno prireditveno dejavnost tudi s področja zdravja, manj pa sta poznana vloga in delovanje zdravstvenih kotičkov pri izobraževanju za zdravje. Namen raziskave je predstaviti, kakšne zdravstvene informacije in storitve ponujajo knjižnice svojim uporabnikom s pomočjo zdravstvenih kotičkov in s kakšnimi izzivi se srečujejo pri izobraževanju za zdravje med uporabniki.

\section{METODOLOGIJA}

Za namen raziskave smo si zastavili naslednja raziskovalna vprašanja:

- Kako delujejo zdravstveni kotički v slovenskih splošnih knjižnicah?

- Katere so prednosti delovanja zdravstvenih kotičkov in s kakšnimi izzivi se soočajo?

- Kako uporabniki splošnih knjižnic iščejo zdravstvene informacije in kako uporabljajo zdravstvene kotičke?

Raziskava je bila zasnovana kot kvalitativna (Flick, 2018). Da bi odgovorili na zastavljena raziskovalna vprašanja, smo podatke zbirali na več načinov, s kombinacijo več metod pa smo upoštevali načelo triangulacije na ravni zbiranja podatkov.

Podatke smo zbirali (a) z analizo virov, spletnih strani in družbenih omrežij knjižnic, (b) z obiskom knjižnic, opazovanjem, fotografiranjem zdravstvenih kotičkov in (c) z intervjuji knjižničarjev. V raziskavi je bil uporabljen polstrukturiran intervju z vnaprej pripravljenimi odprtimi vprašanji. Podatke smo zbirali od marca 2020 do avgusta 2021. Intervjuje smo opravili junija in avgusta 2021, izvedli smo tri osebne in en telefonski pogovor s knjižničarji, ${ }^{2}$ ki so pristojni za zdravstvene kotičke. Sodelujočim smo zagotovili anonimnost njihovih odgovorov in zaupnost podatkov. Zbrani podatki so bili analizirani z metodo analize besedila. Po analizi besedil smo ugotovitve združili v teme, ki so sledile raziskovalnim vprašanjem. Rezultate $\mathrm{v}$ nadaljevanju prikazujemo najprej po posameznih lokacijah zdravstvenih kotičkov in nato glede na izzive, s katerimi se srečujejo.

\section{PRIKAZ REZULTATOV}

Samo nekatere osrednje območne knjižnice informirajo uporabnike glede zdravja in izobraževanja za zdravje s pomočjo zdravstvenih kotičkov. To so: Mestna knjižnica Kranj, Mestna knjižnica Ljubljana, Mariborska knjižnica in Knjižnica Mirana Jarca Novo mesto.

2 Uporabljena je moška oblika kot enotna oblika, tudi zato, da bi s tem popolnoma zakrili identiteto vprašanih knjižničark in knjižničarjev. 
V nadaljevanju predstavljeni zdravstveni kotički v slovenskih splošnih knjižnicah so razvrščeni po letu nastanka.

\section{Zdravstveni kotiček v Mestni knjižnici Ljubljana}

V letu 2011 je začel delovati prvi zdravstveni kotiček, to je bilo v Knjižnici Otona Župančiča v Mestni knjižnici Ljubljana, z namenom, da bi izobraževali in pomagali pri iskanju relevantnih informacij. Kasneje so zasnovali tudi Demenci prijazno točko. Zdravstveni kotiček in Demenci prijazna točka delujeta v prvem nadstropju. Na voljo so računalnik za iskanje informacijskih virov o zdravju, zloženke, revije in zgibanke ter zbirka knjig. Uporabniki segajo po razstavljeni literaturi in brošurah v kotičku. Ugotovitve iz pogovorov in opazovanja kažejo, da mlajši iščejo e-vire sami doma. Starejši in manj izobraženi niso tako motivirani in se slabše znajdejo pri iskanju e-virov, tudi zaradi težav pri uporabi računalnika. Iskanje se jim zdi zahtevno zaradi velike količine informacij in si želijo predvsem informacije iz tiskanega gradiva, kot so knjige, enciklopedije, leksikoni itd. V začetku delovanja zdravstvenega kotička so v knjižnici glede nakupa gradiva dobili kakšno priporočilo ali opozorilo Centralne medicinske knjižnice, v splošnem pa se odzivajo na povpraševanje uporabnikov, zato imajo literaturo (tudi $\mathrm{v}$ tujem jeziku) o alternativnih in komplementarnih načinih zdravljenja in skrbi za dobro počutje. Veliko imajo na voljo tudi študijskega gradiva, ki si ga izposojajo predvsem študenti in dijaki. Pri iskanju primernega tiskanega gradiva med policami starejši uporabniki pogosto izrazijo svoje težave z zdravjem in si želijo pogovora s knjižničarjem.

Najbolj so obiskane brezplačne dejavnosti: predavanja, delavnice, tečaji, meritve tlaka in sladkorja v krvi. Ob tem so se, predvsem starejši uporabniki, radi pogovarjali o svojih zdravstvenih težavah z izvajalci teh meritev. Preventivnih akcij se je v obdobju 2014-2017 v 33 terminih udeležilo 545 uporabnikov in zaposlenih v knjižnici. V okviru zdravstvenega kotička so bili načrtovani tedenski obiski in prisotnost strokovnjaka prostovoljca, ki naj bi v knjižnici dajal strokovne informacije. Zaradi majhnega obiska so tovrstno svetovanje po dveh mesecih opustili. Po drugi strani pa se je število prireditev na tematiko zdravja iz leta $\mathrm{v}$ leto povečevalo. Te se ne odvijajo v zdravstvenem kotičku, temveč v dvorani. Med letoma 2011 in 2017 so organizirali 205 prireditev, ki se jih je udeležilo 10.201 obiskovalcev, poleg tega so pripravili še 95 razstav (gl. Resman, 2018).

Leta 2016 je bila na spletni strani Mestne knjižnice Ljubljana postavljena Infotočka e-gradiv javnih oblasti, ${ }^{3}$ ki vključuje eZdravje s sklopi. Na spletni strani zdravstvenega kotička ${ }^{4}$ pa so navedene storitve, ki jih ponujajo svojim uporabnikom: pomoč knjižničarja, knjižnična zbirka, predavanja, brezplačne meritve krvnega tlaka in sladkorja, razstave in zloženke ter publikacije $\mathrm{z}$ informacijami o zdravju in delovanju društev. Vendar pa navedene storitve nimajo hiperpovezav, ki bi vodile na Infotočko e-gradiv javnih oblasti. Na družbenih omrežjih je Mestna knjižnica zelo dejavna, redno promovira dogodke in

3 Infotočka je dostopna na https://www.mklj.si/infotocka-e-gradiv-javnih-oblasti/ezdravje/.

4 Spletna stran zdravstvenega kotička je dostopna na https://www.mklj.si/zdravstveni-koticek/. 
predavanja na temo zdravja, bralne sezname, nekaj objav pa je bilo tudi $\mathrm{v}$ povezavi $\mathrm{z}$ zdravstvenim kotičkom.

Kot smo omenili v uvodu, je pri razvoju zdravstvene pismenosti pomembno tudi profesionalno izobraževanje knjižničarjev, ki dejavnosti razvijajo in organizirajo. Tako smo pri raziskovanju prakse izobraževanja za zdravje ugotovili, da se je knjižničar izobraževal z obiski v tujini. Poleg izobraževanja v Centralni medicinski knjižnici je zaposleni v okviru Erasmusu+ obiskal splošno knjižnico v Veliki Britaniji in se seznanil z njihovimi storitvami pri izobraževanju za zdravje. Za širšo skupnost knjižničarjev pa je Mestna knjižnica Ljubljana pripravila različne predstavitve in izobraževanja ter zasnovala predavanje za knjižnične delavce Zdravstveno opismenjevanje v splošni knjižnici.

Oblikovali so tudi koncept Borza zdravja, ki celostno obravnava posredovanje zdravstvenih informacij in zdravstveno opismenjevanje v Mestni knjižnici Ljubljana.

\section{ZDRAVstveni KOTiček v Knjižnici Mirana Jarca Novo mesto}

V Knjižnici Mirana Jarca Novo mesto so leta 2011 uredili zdravstveni kotiček, v katerem so različne zloženke, predvsem pa plakati s področja zdravja. Zloženke so oblikovali z namenom, da bo iskanje želene literature enostavno in hitro. Opremili so jih tudi z dodatnimi informacijami in povezavami na spletne strani iskane tematike. Ob zdravstvenem kotičku je prostor za iskanje informacij na računalniku. Razstave s področja zdravja pripravljajo tudi na razstavnem panoju na hodniku ob vhodu v knjižnico, v knjižnici ali na oddelku, ki je povezan s posamezno ciljno skupino (npr. razstava o dojenju je bila na otroškem oddelku knjižnice). Ob tem priložnostno razstavijo tudi izbrano gradivo. Na panojih je izpostavljen logotip zdravstvenega kotička, na panoju ob vhodu pa tudi logotip NIJZ, saj knjižnica redno sodeluje z Nacionalnim inštitutom za javno zdravje. Sodelujejo tudi z zdravstvenim domom in različnimi organizacijami in društvi, ki delujejo na področju zdravja in preventive. Zelo dobre izkušnje in odzive imajo na celodneven dogodek s predavanji, delavnicami in razstavo, ki ni nujno lokacijsko vezana samo na zdravstveni kotiček. Trenutne obiskovalce knjižnice nagovorijo k udeležbi na delavnici ali predstavitvi, in ko se oblikuje dovolj velika skupina, jo izvedejo. V njihovi praksi lahko v ospredje postavimo element animacije uporabnikov. Tovrsten način izvedbe se je izkazal kot učinkovit, saj je udeležba večja kot pri vnaprej razpisanih, fiksnih terminih.

Gradivo, predvsem knjige s področja zdravja, ni postavljeno v zdravstvenem kotičku ali njegovi neposredni bližini. Odgovorni za zdravstveni kotiček deluje proaktivno in samoiniciativno: daje predloge za dogodke, jih organizira in izvede, daje pobude za objave na družbenih omrežjih, kontaktira NIJZ in sodelujoče pri pripravi razstav itd.

Na spletni strani so oblikovali virtualni zdravstveni kotiček ZDRAVstveni KOTiček, ${ }^{5}$ ki ima podstrani Zdravstveni viri in Aktualno. Na predstavitveni strani so ponujene spletne povezave na informacije o koronavirusu (predvsem na NIJZ in aktualne podatke $\mathrm{v}$

5 Virtualni ZDRAVstveni KOTiček je dostopen na https://www.nm.sik.si/si/studijski/zdravstveni-koticek/. 
Mestni občini Novo mesto). Ponujeni so e-viri tujih založnikov v angleščini. Na podstrani Zdravstveni viri so kratki opisi spletnih virov in povezave na slovenske spletne strani, na podstrani Aktualno pa program Svit. Knjižnica Mirana Jarca Novo mesto je dejavna na Facebooku. Tam skrbi za splošne objave s področja zdravja, spodbuja k zdravemu načinu življenja in vabi k solidarnosti ter krvodajalstvu. Objave sicer prejmejo majhen odziv, kar pa ni nujno najboljši kazalnik pomembnosti in branosti med uporabniki.

\section{Bralna lekarna v Mariborski knjižnici}

V enoti Nova vas pri Mariborski knjižnici od leta 2013 deluje zdravstveni kotiček, ki so ga poimenovali Bralna lekarna. Poleg strokovne literature, predvsem revij, knjižničarji ponujajo zlasti poljudna dela, ki se dotikajo različnih bolezenskih stanj. Gradivo izbira ambasador knjižnice mag. Aco Prosnik, ki dvakrat letno vodi tudi pogovor z avtorji poljudnih del, ki opisujejo določene zdravstvene težave (npr. pogovor o knjigi Hipokrat je bil kuhar: poti iz medicinskih in prehranskih zablod z avtorjem Ivanom Sočejem).

Na spletni strani Mariborske knjižnice nimajo podstrani, ki bi ponujala informacije o Bralni lekarni. Na spletni strani »Kako smo se imeli« je navedeno le poročilo s treh dogodkov iz leta 2013 (Zdravstveni bralni kotiček v Knjižnici Nova vas), 2015 (Zdravstveni kotiček: Glava dela čudeže) in 2016 (Bralna lekarna: Predstavitev knjige Hipokrat je bil kuhar). Na družbenih omrežjih (Facebook in Instagram) je knjižnica zelo dejavna, vendar posebnega poudarka na izobraževanju za zdravje nismo zasledili.

Idejna zasnova zdravstvenega kotička se je preoblikovala, saj ne deluje v prvotno zastavljenih okvirih projekta zdravstvenih kotičkov.

\section{Zdravstveni kotiček v Mestni knjižnici Kranj}

Najnovejši slovenski zdravstveni kotiček je bil v Mestni knjižnici Kranj odprt leta 2017, leta 2021 pa so postali tudi Demenci prijazna točka. Kotiček je v drugem nadstropju, oblikovan je prostorno, ima nekaj sedežev, mizo in stole, izpostavljene so revije, zgibanke in tematsko obarvane monografije, ki jih priložnostno menjujejo. V neposredni bližini je knjižnično gradivo s področja zdravja.

V zdravstvenem kotičku ali dvorani izvajajo delavnice za različne specifične skupine (npr. za nosečnice in mlade mamice) ali uporabnike s specifičnimi težavami (npr. težavami s prekomerno težo). Vse dogodke objavijo v Mesečniku - napovedniku dogodkov v Mestni knjižnici Kranj. Večje število obiskovalcev ob dogodku v zdravstvenem kotičku je lahko moteče za preostale obiskovalce knjižnice, ki iščejo gradivo ali želijo več tišine zaradi študija ali branja. Zato so dogodke izvedli v času zaprtosti knjižnice, vendar je treba $\mathrm{v}$ tem primeru poskrbeti za večjo varnost celotne knjižnice in zagotoviti ob koncu prireditve skupen odhod obiskovalcev iz knjižnice. Zdravstveni kotiček je namenjen bolj pogovorom in predstavitvam, manj pa predavanjem, saj ni opremljen $\mathrm{z}$ avdio-vizualno opremo, ki bi omogočala projekcije in ozvočenje. Tako se večina izobraževanj za zdravje izvede v knjižnični dvorani, ki ima najboljše pogoje za obiskovalce in predavatelje. 
Opazno je sodelovanje med knjižnico in zdravstveno ustanovo, saj na spletni strani Zdravstvenega doma Kranj oglašujejo dogodke, ki se odvijajo v zdravstvenem kotičku (Zdravstveni dom Kranj, 2021).

Mestna knjižnica Kranj ima na spletni strani podstran Zdravstveni kotiček, ${ }^{6}$ kjer so predstavljeni razlogi za obstoj, lokacija in aktivnosti zdravstvenega kotička: pomoč pri iskanju zdravstvenih informacij, predavanja, tečaji in zaznamovanje svetovnega dneva zdravja. V letu 2021 so v sodelovanju s Centrom za krepitev zdravja posneli kratke, 15-minutne oddaje $\mathrm{Na}$ zdravje na temo prehrane, o krepitvi imunskega sistema, čiščenju zob in aerobni vadbi. Med družbenimi omrežji so dejavni na Facebooku, Instagramu in Twitterju. Na Facebooku objavljajo sporočila o zdravju, ki jih posredujejo od drugih institucij (npr. Preventivni program za odrasle, 21. 12. 2017), zaznamujejo svetovni dan zdravja (npr. svetovni dan zdravja, 7. 4. 2021) in napovedujejo dogodke v zdravstvenem kotičku, predavanja (npr. o ledvicah in ledvičnih boleznih, 19. 3. 2018) ali pa poročajo o povezovanju z zdravstvenimi ustanovami (obisk kranjske porodnišnice in izročitev pisma iz knjižnice novorojenčkom, 15. 6. 2021). Na Instagramu so objavili dva videa Na zdravje: okrepimo imunski sistem (93 ogledov, 3. 2. 2021) in o povišanem krvnem tlaku (97 ogledov, 8. 12. 2020). V okviru cikla Znanost na cesti je bilo izvedeno tudi predavanje Bliskovit razvoj cepiv proti novemu koronavirusu SARS-COV-2 (16. 10. 2020), poleg tega promovirajo knjižnično gradivo, npr. promocija prek treh naslovnic knjig o epidemiji skozi čas (12. 10. 2020).

\section{Izzivi zdravstvenih kotičkov v slovenskih splošnih knjižnicah}

Ob snovanju projekta zdravstvenih kotičkov je opazno veliko pričakovanje in navdušenje, vendar se je skozi čas izkazalo, da se ti soočajo z mnogimi izzivi in problemi pri ureditvi ustreznega prostora, zagotavljanju prisotnosti zaposlenih, posredovanju informacij, organizaciji dogodkov ter pri izobraževanju in povezovanju knjižničarjev.

\section{Ustrezen prostor in zagotavljanje prisotnosti zaposlenih oz. zdravstvenih strokovnjakov}

Splošne knjižnice so zdravstvene kotičke umestile v zatišni del knjižnice, kajti vsak prostor ni primeren za ta namen. V kotičku naj bi se odvijali referenčni pogovori s področja zdravja, pogovori z zdravnikom, farmacevtom ali zdravstvenim delavcem, ki bi redno prihajal v knjižnico. Za tovrstne pogovore bi prostor moral omogočati večjo zaupnost in zasebnost. Za druge dogodke so zdravstveni kotički premajhni, sploh če pritegnejo večje število obiskovalcev. Če je okrog kotička postavljeno gradivo, takšne pogovore motijo uporabniki, ki iščejo gradivo. Zaradi odmaknjenosti kotičkov od knjižničarjev pa ti nimajo večjega pregleda, nadzora ali možnosti spremljanja dejanske uporabe zdravstvenega kotička. Pogostejša prisotnost knjižničarjev v zdravstvenem kotičku bi ponudila priložnosti za pogovore z uporabniki, ki bi enostavneje izrazili potrebe po zdravstvenih informacijah, po drugi strani pa bi zahtevala reorganizacijo dela zaposlenih.

6 Podstran je dostopna na https://www.mkk.si/asset/p5m6ZrKGRXXWiWhTA. 


\section{Posredovanje informacij}

Izkušnje glede povpraševanja po zdravstvenih informacijah so različne. Knjižnice ne vodijo posebne statistike, koliko je kotiček dejansko obiskan in uporabljan. Od posameznika in njegovih osebnostnih značilnosti je odvisno, ali bo za pomoč pri iskanju zdravstvenih informacij vprašal knjižničarja. Mnogi, predvsem starejši, vprašajo knjižničarja v knjižnici, nekateri pa vprašajo tudi prek drugih komunikacijskih kanalov. V referenčnem pogovoru uporabnik izrazi, kakšna je njegova informacijska potreba, $v$ tem pogovoru pa se mora s knjižničarjem vzpostaviti tudi zaupanje. Pri tem je od uporabnika, knjižničarja in preostalih navzočih v prostoru odvisno, koliko jasno jo bo uporabnik definiral. Nekateri govorijo zelo naglas, po drugi strani pa nekatere uporabnike lahko moti že navzočnost drugih knjižničarjev ali uporabnikov, ki so v bližini.

Glede na veliko količino relevantnega gradiva, ki je v knjižnici na voljo, je ta proces usmerjanja in svetovanja o informacijah ali virih zahteven.

\section{Organizacija dogodkov}

Mnogi uporabniki knjižnice ne pričakujejo, da bodo določene storitve, povezane z zdravjem, dobili v knjižnici, zato je potreben čas, da se ljudje navadijo na neke dejavnosti in da se udomačijo v prostoru knjižnice. V nekaterih knjižnicah izvajajo razne zdravstvene meritve, v drugih ne. Razlogi, da teh meritev (npr. krvnega tlaka) ne izvajajo, so lahko slabša obiskanost ali stroški, povezani z nabavo ustreznega materiala in plačilom honorarja izvajalcem.

Predavanja in delavnice za zdravje so dobro obiskani. Odgovorni za zdravstvene kotičke samo ponekod sodelujejo pri izbiri tematike predavanj in predavateljev. Število obiskovalcev prireditev je v splošnem težko predvidljivo, razen pri znanih predavateljih, ko je že vnaprej zagotovljena dobra obiskanost. Izbira predavateljev je zahtevna in običajno previdnost ni odveč, kot so poudarili moji sogovorniki $v$ intervjujih. Veliko prednost in hkrati izziv pomeni navezovanje in vzpostavitev stikov z zdravstvenimi ustanovami in društvi v lokalnem okolju. Kot pri vseh knjižničnih prireditvah je pomemben čas izvajanja nekega dogodka. Če so dogodki v času odprtosti knjižnice, je lahko moteče za preostale uporabnike, če pa se izvajajo v času zaprtosti, je treba poskrbeti za varnost prostorov. Vsebina izobraževanj pritegne različno starostno strukturo obiskovalcev, npr. mladi pridejo na delavnice prve pomoči, starejši na meritve tlaka. Celodnevni dogodki so zahtevni z vidika organizacije, vendar se opaža veliko prednosti, kot je npr. učinkovitejša promocija, večja prepoznavnost in vidnost, boljša obiskanost in lažja organizacija delavnic. Zdravstveni kotički so postali na neki način razstavni prostori za gradivo, revije, letake itd., dogodki pa se odvijajo v dvoranah, kjer je na voljo tudi vsa oprema za izvedbo predavanj.

Med epidemijo covida-19 so dejavnosti v zdravstvenem kotičku opustili, nekatera predavanja in izobraževanja za zdravje so izvedli na internetu. 


\section{Izobraževanje zaposlenih in medsebojna povezanost knjižnic z zdravstvenimi kotički}

Velika prednost knjižnic, ki imajo zdravstvene kotičke, so dodatno izobraženi knjižničarji. Ti so se izobraževali glede uporabe zdravstvenih virov, kar je organizirala Centralna medicinska knjižnica. V okviru Erasmusa+ je knjižničar spoznal tudi dobre prakse tujih knjižnic. Kasneje pa se knjižničarji niso več organizirano izobraževali, temveč so samostojno iskali primere dobrih praks $\mathrm{v}$ različnih virih, se povezovali z nacionalnimi in lokalnimi institucijami. Manjka večja povezanost med knjižničarji knjižnic, ki imajo vzpostavljene zdravstvene kotičke. Nekateri dogodki ali razstave bi lahko postali potujoči oz. bi se izvedli v več knjižnicah, ki nimajo prostorskih ali zaposlitvenih zmogljivosti za zdravstveni kotiček.

\section{DISKUSIJA}

$\mathrm{Z}$ raziskavo smo želeli osvetliti delovanje splošnih knjižnic pri izobraževanju za zdravje, ugotovitve kažejo, da obstaja veliko inovativnih praks, ki pa se morajo stalno prilagajati.

Zamisel zdravstvenih kotičkov je dobra, pričakovanja velika, vendar zdravstveni kotički ne delujejo tako, kot so bili v začetku zasnovani. Da bi bilo delovanje optimalno in bi uporabniki knjižnice in lokalna skupnost imeli več koristi, bi bilo treba poiskati nove možnosti, priložnosti in rešitve ter vzpostaviti predvsem stike z ministrstvi in zdravstvenimi institucijami ter nenehno spremljati potrebe ljudi v lokalnem okolju. Treba bi bilo najti nove oblike izobraževanja, ki bi jih lahko vključili neposredno v zdravstvene kotičke, kar vse prinaša finančne in profesionalne izzive.

Trenutno so zdravstveni kotički namenjeni predvsem razstavam, brskanju po brošurah, revijah in izpostavljenem gradivu, lahko pa tudi študiju ali delu na računalniku, ki ni (nujno) povezano z izobraževanjem za zdravje. Največ informacij s področja zdravja posredujejo uporabnikom v tiskani obliki, zato računalnik v zdravstvenem kotičku ne opravlja funkcije, zaradi katere je bil tja nameščen. Po drugi strani pa je opazno digitalno razhajanje pri starejših, ki so manj vešči iskanja po spletu ali različnih podatkovnih bazah. Glede na hiter proces staranja prebivalstva tako v Evropi kot tudi v Sloveniji je potrebna večja angažiranost knjižnic pri delu s starejšimi, ki imajo drugačne potrebe kot mlajši ter kažejo primanjkljaj na področju informacijske pismenosti. Razvite IKT-spretnosti so eden izmed pogojev za izobraževanje za zdravje, saj je vedno več zdravstvenih informacij v digitalni obliki. Zato starejši, ki so manj vešči iskanja po spletu ali različnih podatkovnih bazah, iščejo predvsem tiskano gradivo, kar je ugotovil tudi Ingham (2014). Prav starejši radi poklepetajo s knjižničarji o zdravju, o čemer so pisali tudi Linnan idr. (2004), kar kaže na potrebo, da knjižničarji temu namenijo dodaten čas in tudi razvijejo profesionalne spretnosti usmerjanja in svetovanja.

Glede na to, da se v knjižnicah zaznava potreba po zdravstvenih informacijah in izobraževanju za zdravje, bi morali razmisliti tudi o prostorski umestitvi zdravstvenega kotička v knjižnici, saj se večina predavanj izvede v knjižnični dvorani oz. prireditvenem prostoru, 
kjer je na voljo tudi vsa oprema (ozvočenje, projektor, stoli itd.). Kot pomanjkljivost je zaznati, da knjižničarji, ki so pristojni za zdravstvene kotičke, nimajo vedno vpliva na izbiro predavateljev in tematik predavanj s področja zdravja. Velik potencial imajo knjižnice tudi zaradi vzpostavljenih stikov z organizacijami, ki se ukvarjajo s področjem zdravja. $\mathrm{Na}$ ta način bi lahko nastalo še več kakovostnih izobraževanj in spletnih vsebin. Ena od priložnosti je tudi izboljšanje medsebojnega sodelovanja in povezovanja med knjižnicami z zdravstvenimi kotički, ki bi imelo za knjižničarje in lokalno skupnost veliko prednosti.

Čeprav so se razmere po pandemiji covida-19 bistveno spremenile, pa večjih sprememb ali prilagoditev glede izobraževanj za zdravje ni zaznati (razen nekaj videoposnetkov). Zdi se, da so vsi v pripravljenosti in čakajo, da bodo ob sproščanju zdravstvenih ukrepov ponovno začeli izvajati dejavnosti, ki so jih imeli pred pandemijo.

Izobraževanje za zdravje naj bi bilo namenjeno vsem družbenim skupinam, a naše ugotovitve kažejo, da mladi kljub kompleksnosti podatkovnih baz ne izražajo potrebe po pomoči knjižničarjev pri iskanju relevantnih zdravstvenih informacij, zelo malo pa je dogodkov, ki bi namensko nagovarjali to starostno skupino. Objav z zdravstveno tematiko je na družbenih omrežjih knjižnic relativno malo, čeprav je v trenutnem obdobju verjetno to najbolj smotrna pot, saj bi z objavami (morda tudi plačanimi) lažje dosegli mlajše uporabnike in neuporabnike knjižnic.

Izvedba raziskave ima svoje prednosti in slabosti. Največja prednost je v tem, da smo analizirali vse knjižnice, ki imajo zdravstveni kotiček, in izvedli intervjuje s knjižničarji, ki skrbijo in vodijo zdravstvene kotičke ter so prepričani o pomembnosti izobraževanja za zdravje lokalnega prebivalstva. Naše ugotovitve tako izhajajo predvsem z zornega kota organizatorjev izobraževanja, zato bi morali raziskavo nadaljevati s proučevanjem, kakšna je uporabniška izkušnja zdravstvenih kotičkov, kako uporabniki pridobivajo in uporabljajo informacije v zdravstvenih kotičkih ter kakšen je vpliv pridobljenih informacij na večjo kakovost njihovega življenja. Rezultati večje raziskave, v katero bi bile vključene vse slovenske splošne knjižnice, bi morda pokazali, kakšno je splošno mnenje glede izobraževanja za zdravje, katere aktivnosti knjižnice še izvajajo in ali imajo izoblikovane drugačne strategije in načrte glede izobraževanja za zdravje. Raziskava se je izvajala v izredno negotovem času epidemije covida-19, ko so knjižnice zaradi zdravstvenih ukrepov omejene pri izvajanju svojih dejavnosti. Večina aktivnosti se seli na splet, kjer pa je tudi večina iskalcev zdravstvenih informacij (Andreassen idr., 2007; Ramšak, 2011; Traver idr., 2016).

\section{ZAKLJUČEK}

$\mathrm{Z}$ raziskavo smo naredili prvo in celotno analizo delovanja zdravstvenih kotičkov ter postavili v ospredje izzive, s katerimi se soočajo.

Izobraževanje za zdravje je $\mathrm{v}$ splošnih knjižnicah zelo fluidna praksa in se premika med različnimi strategijami: včasih je bolj intenzivno delo v zdravstvenih kotičkih, včasih pa v obliki večjih prireditev v prireditvenih prostorih oz. dvoranah. Glede na to, da se število prireditev z zdravstveno tematiko povečuje, prireditve pa so dobro obiskane, so 
zdravstveni kotički kot del celovite strategije animacije, ozaveščanja in izobraževanja o zdravju dosegli cilj. Žal pa knjižnice ne vodijo evidence o uporabi ali obiskanosti zdravstvenega kotička ali koliko je ta pripomogel k večji informiranosti o zdravju in boljši kakovosti življenja. Za tovrstne ugotovitve bi morali raziskavo nadaljevati z vključitvijo uporabnikov.

Knjižnice so pomemben center za izobraževanje odraslih, in da bi zdravstveni kotički $\mathrm{v}$ polnosti izpolnjevali svojo vlogo in namen, bi se morali preoblikovati in razviti nove strategije izobraževanja za zdravje. Ker je knjižnica stičišče lokalne skupnosti vseh družbenih slojev, lahko nagovarja tudi marginalizirane skupine, zato so ti kotički priložnost za srečevanje manjših skupin. Mnogi prihajajo v knjižnico tudi z namenom, da se lahko s kom pogovarjajo, zato knjižničarjem pripovedujejo o svojih zdravstvenih težavah. Z vključenostjo v majhne medgeneracijske skupine ali pare, ki bi jih vodili prostovoljci, bi ponudili nove oblike druženja in pogovora o zdravju.

Potrebna bi bila večja promocija zdravstvenih kotičkov, knjižnice bi lahko bolj izkoristile moč interneta, predvsem družbenih omrežij. Z različnimi pristopi, vsebinami v različnih oblikah (besedilo, zvok, slika, video) bi za zdravje izobraževali vse prebivalce lokalne skupnosti (tudi nečlane). Te dejavnosti bi bile zelo pomembne tudi zaradi vedno večje invazije lažnih novic na področju zdravja.

Ugotovili smo, da knjižnice, ki imajo zdravstvene kotičke, že sodelujejo z zdravstvenimi ustanovami, društvi in organizacijami v lokalnem okolju, a so po drugi strani premalo prepoznane s strani društev kot prostor za srečevanje ljudi s podobnimi zdravstvenimi težavami. Opazna je odsotnost medsebojnega povezovanja med knjižnicami pri izobraževanju za zdravje, kar bi prineslo večje koristi tudi za tiste knjižnice, ki zdravstvenih kotičkov še nimajo. Pri načrtovanju in izvedbi novih pristopov bi bilo vsekakor dobrodošlo sodelovanje različnih strokovnjakov.

\section{LITERATURA IN VIRI}

Andreassen, H. K., Bujnowska-Fedak, M. M., Chronaki, C. E., Dumitru, R. C., Pudule, I., Santana, S., Voss, H. in Wynn, R. (2007). European citizens' use of E-health services: A study of seven countries. BMC public health, 7(1), 1-7. https://doi.org/10.1186/1471-2458-7-53

Anker, A. E., Reinhart, A. M. in Feeley, T. H. (2011). Health information seeking: A review of measures and methods. Patient education and counseling, 82(3), 346-354. https://doi.org/10.1016/j. pec.2010.12.008

Bennett-Kapusniak, R. K. (2018). Public library programs and services for midlife and beyond: Expanding opportunities for a growing population. ABC-CLIO.

Collins, L. N. (2015). Healthy libraries develop healthy communities: Public libraries and their tremendous efforts to support the Affordable Care Act. Journal of consumer health on the Internet, 19(1), 68-76. https://doi.org/10.1080/15398285.2014.988467

Coulter, A., Ellins, J., Swain, D., Clarke, A., Heron, P., Rasul, F. in Sheldon, H. (2006). Assessing the quality of information to support people in making decisions about their health and healthcare. Picker Institute Europe. http://citeseerx.ist.psu.edu/viewdoc/download?doi=10.1.1.108.4236\&rep=rep1\&type=pdf 
Delić, D., Polašek, O. in Kern, J. (2006). Internet health-information seekers in Croatia-who, what, and why? Medical informatics and the Internet in medicine, 31(4), 267-273. https://doi. org/10.1080/14639230600991726

Estacio, E. V. in Comings, J. (2013). Health literacy: Exploring future directions and potential contributions from health psychology. Journal of Health Psychology, 18(8), 997-1003. https://doi. org/10.1177/1359105313476978

Flick, U. (2018). An Introduction to Qualitative Research. Sage.

Fox, S. in Duggan, M. (2013). Health online 2013. Pew Internet \& American Life Project. https://www. ordinedeimedici.com/documenti/Docs7-cybercondria-PIP-HealthOnline.pdf

Fox, S. in Rainie, L. (2002). How Internet users decide what information to trust when they or their loved ones are sick. Pew Internet \& American Life Project.

Huotari, M. L., Enwald, H., Hirvonen, N., Keränen, A.-M., Jokelainen, T., Salonurmi T. in Niemelä, R. (2015). Everday health information literacy in counselling on healthy eating: The case of PrevMetSyn. V S. Kurbanoglu, S. Špiranec, E. Grassian, D. Mizrachi in L. Roy (ur.), Information literacy: Moving toward sustainability: Third European Conference, ECIL 2015, Tallinn, Estonia, October 19-22, 2015, Revised Selected Papers (zbirka Communications in Computer and Information Science, št. 552, str. 223-232). Springer. https://doi.org/10.1007/978-3-319-28197-1_23

Ingham, A. (2014). Can your public library improve your health and well-being? An investigation of East Sussex Library and Information Service. Health Information \& Libraries Journal, 31(2), 156-160. https://doi.org/10.1111/hir.12065

Kickbusch, I. (2008). Health literacy: An essential skill for the twenty-first century. Health Education, 108(2), 101-104. https://doi.org/10.1108/09654280810855559

Kodela, T. (2015). Po nova znanja za knjižnico, 2. del - v Stoke-on-Trent v Veliko Britanijo. Knjižničarske novice, 25(8/9), 22-25.

Komel, A. (2016). Študija uporabnikov medicinske literature v Goriški knjižnici Franceta Bevka [Diplomsko delo]. Univerza v Ljubljani, Filozofska fakulteta.

Kozel, J. (2010). Uporaba interneta v zdravstvene namene [Diplomsko delo]. Univerza v Mariboru, Fakulteta za elektrotehniko, računalništvo in informatiko.

Linnan, L. A., Wildemuth, B. M., Gollop, C., Hull, P., Silbajoris, C. in Monnig, R. (2004). Public librarians as a resource for promoting health: Results from the Health for Everyone in Libraries Project (HELP) librarian survey. Health Promotion Practice, 5(2), 182-190. https://doi. org/10.1177/1524839903258018

Morgan, A. U., Dupuis, R., D’Alonzo, B., Johnson, A., Graves, A., Brooks, K. L., McClintock, A., Klusaritz, H., Bogner, H., Long, J. A., Grande, D. in Cannuscio, C. C. (2016). Beyond books: Public libraries as partners for population health. Health Affairs, 35(11), 2030-2036. https://doi.org/10.1377/ hlthaff.2016.0724

Nacionalni inštitut za javno zdravje. (2021). Projekt Dvig zdravstvene pismenosti v Sloveniji (ZaPiS). https://www.nijz.si/sl/projekt-zapis-dvig-zdravstvene-pismenosti-v-sloveniji

Nacionalni svet za knjižnično dejavnost. (2018). Strokovna priporočila in standardi za splošne knjižnice (za obdobje 2018-2028). https://www.gov.si/assets/ministrstva/MK/Zakonodaja-ki-ni-na-PISRS/ Kulturna-dediscina/2ffbd52377/Strokovna-priporocila-in-standardi-za-splosne-knjiznice.pdf

Narodna in univerzitetna knjižnica. (2021). BibSiSt Online: Statistični podatki o knjižnicah. http://bibsist.nuk.uni-lj.si/

Pálsdóttir, Á. (2014). Preferences in the use of social media for seeking and communicating health and lifestyle information. Information Research: An International Electronic Journal, 19(4). 
Pletneva, N., Vargas, A. in Boyer, C. (2011). How do general public search online health information. Health On the Net Foundation. https://www.hon.ch/Global/pdf/Khresmoi/KRESMOI_internet_health_search_information_HON.pdf

Powell, J., Inglis, N., Ronnie, J., in Large, S. (2011). The characteristics and motivations of online health information seekers: Cross-sectional survey and qualitative interview study. Journal of medical Internet research, 13(1), e20. https://doi.org/10.2196/jmir.1600

Radick, L. (2015). Improving health literacy, one public library at a time. American Libraries, 46(11/12), $48-53$.

Ramšak, M. (2011). V pričakovanju e-zdravja: Medicina, tehnologija, družba in etika. Etnolog: glasnik Slovenskega etnografskega muzeja, 21(72), 35-55.

Resman, S. (2018). Borza zdravja v MKL: Smernice za delovanje. Mestna knjižnica Ljubljana. https:// www.mklj.si/wp-content/uploads/2021/04/Borza_zdravja.pdf

Rožić, A., Tržan-Herman, N. in Jakac-Bizjak, V. (2010). Zdravstveni kotiček - delo na projektu "Splošne knjižnice za zdravje občanov". Knjižničarske novice, 20(10), 11-15.

Rubenstein, E. L. (2016). Health information and health literacy: Public library practices, challenges, and opportunities. Public Library Quarterly, 35(1), 49-71. https://doi.org/10.1080/01616846.2016. 1163974

Sørensen, K., Van den Broucke, S., Fullam, J., Doyle, G., Pelikan, J., Slonska, Z. in Brand, H. (2012). Health literacy and public health: A systematic review and integration of definitions and models. BMC public health, 12(1), 1-13. https://doi.org/10.1186/1471-2458-12-80

Svet referenčnih in uporabniških storitev Ameriškega knjižničarskega združenja. (2015). Health and medical reference guidelines. https://www.ala.org/rusa/resources/guidelines/guidelinesmedical

Šinko, S. (2012). Splošne knjižnice in izobraževanje odraslih. Andragoška Spoznanja, 18(3), 53-61. https://doi.org/10.4312/as.18.3.53-61

Švab, K. (2020). Facebook, Instagram in Twitter osrednjih območnih knjižnic med karanteno zaradi COVID-19. Knjižničarske novice, 30(5), 7-9.

Traver, M., Basagoiti, I., Martinez-Millana, A., Fernández-Llatas, C. in Traver, V. (2016, August). Experiences of a general practitioner in the daily practice about Digital Health Literacy: The real needs. $\mathrm{V}$ 38th Annual International Conference of the IEEE Engineering in Medicine and Biology Society (str. 5644-5647). IEEE. https://doi.org/10.1109/EMBC.2016.7592007

Zakon o knjižničarstvu (ZKnj-1). (2001). Uradni list RS, št. 87/1, 96/02. http://www.pisrs.si/Pis.web/ pregledPredpisa?id=ZAKO2442

Zakon o pacientovih pravicah (ZPacP). (2008). Uradni list RS, št. 15/08, 55/17 in 177/20. http://pisrs.si/ Pis.web/pregledPredpisa?id=ZAKO4281

Zdravstveni dom Kranj. (2021). Vabilo na večerne klepete o zdravju v Mestno knjižnico Kranj. https:// www.zd-kranj.si/?subpageid=13\&page $=4 \&$ contid $=259$

Zickuhr, K. (2010). Generations 2010: Online activities. Pew research and Internet Project. https://www. pewresearch.org/internet/2010/12/16/online-activities/ 